\title{
Sporisorium emariae sp. nov. (Ustilaginomycetes) on Sclerachne punctata (Poaceae)
}

\section{Kálmán Vánky}

Herbarium Ustilaginales Vánky (H.U.V.), Gabriel-Biel-Str. 5, D-72076 Tübingen, Germany (e-mail: vanky.k@cityinfonetz.de)

Received 1 December 2012 / Accepted 24 December 2012 / Published 11 January 2013

Vánky, K. 2013. Sporisorium emariae sp. nov. (Ustilaginomycetes) on Sclerachne punctata (Poaceae). Mycobiota 1: 57-61. doi: 10.12664/mycobiota.2013.01.06

Abstract. A new species of Sporisorium, S. emariae on Sclerachne punctata (Poaceae), is described and illustrated from Transcaucasia, Republic of Georgia.

Key words: Chionachninae, smut fungi, Sporisorium emariae, taxonomy

\section{Introduction}

A specimen of smutted Sclerachne punctata, obtained from the late Prof. Zambettakis (PC, Paris) in 1987, was found amongst unidentified specimens in Herbarium Ustilaginales Vánky (H.U.V. 21 981). An incomplete, handwritten label is attached to the specimen with the following text: 'Sphac. T. Sclerachnes Wakf., Sclerachne punctata R. Br., Georgie, 9-10-1907, Clint. Anon. sp.' (sic!). The 'T' is encircled and means 'Type'. 'Wakf.' is an abbreviation for Elsie Maud Wakefield (1886-1927), a remarkable English mycologist active in Kew Herbarium, although the standard abbreviation is correctly Wakef. (Brummitt \& Powell 1992). The word 'Georgie' on the label refers certainly to the Republic of Georgia in the Caucasus region, not to the State of Georgia in the USA. The annotation 'Clint. Anon. sp.' was often made by Zambettakis on his labels. It means that in the monograph of Clinton (1904), no mention of Sphacelotheca sclerachnes was found by Zambettakis. Indeed, there is no mention of Sphacelotheca sclerachnes in Clinton (1904), Zundel (1953) or any other monograph.

The name Sphacelotheca sclerachnes Wakef. is a herbarium name ('nom. herb.'). It was validated as Ustilago sclerachnes Wakef. ex Vánky (2008: 150), on Sclerachne punctata R. Br., Thailand, Bangkok, 10 November 1929 (no further data) (holotype BPI 195063 , isotype probably K(M) 173 932). Sclerachne punctata, known also as Chionachne punctata (R. Br.) Jannik and Polytoca punctata (R. Br.) Stapf ex Hook. f., is a mainly SE Asian grass 
Fig. 1. Sporisorium emariae on Sclerachne punctata (holotype, H.U.V. 21 981). Part of an inflorescence with sori in the racemes mostly hidden by the leaves. Habit, and enlarged and removed sorus. Bars $=1 \mathrm{~cm}$ for habit, and $2 \mathrm{~mm}$ for detail drawing

(Bor 1960; Jannik 2002). On examination, the specimen from SE Asia is morphologically different from that studied and described in this paper from Georgia.

Sclerachne R. Br., together with Chionachne R. Br., Polytoca R. Br., and Trilobachne Henr. belong to the subtribe Chionachninae of the tribe Andropogoneae, subfam. Panicoideae (Clayton \& Renvoize 1986: 371). Nine smut fungi are known on members of Chionachninae (comp. Vánky, 2008: 150-151; 2011). A study of the smut fungus on Sclerachne punctata in H.U.V. 21 981, and comparison with the smut fungi on hosts in the subtribe Chionachninae indicated that it is an unknown species. It is described below.

\section{Materials and methods}

Spore and sterile cell characteristics were studied using dried herbarium specimen. For light microscopy (LM) the spores were suspended in a small droplet of lactophenol, covered with a cover glass, gently heated to boiling point to rehydrate the spores and eliminate air bubbles from the preparation, and examined at 1000× magnification. For scanning electron microscopy (SEM), spores were placed on double-sided adhesive tape, mounted on a specimen stub, sputter-coated with gold, $c a 20 \mathrm{~nm}$, and examined in a SEM at $10 \mathrm{kV}$. 

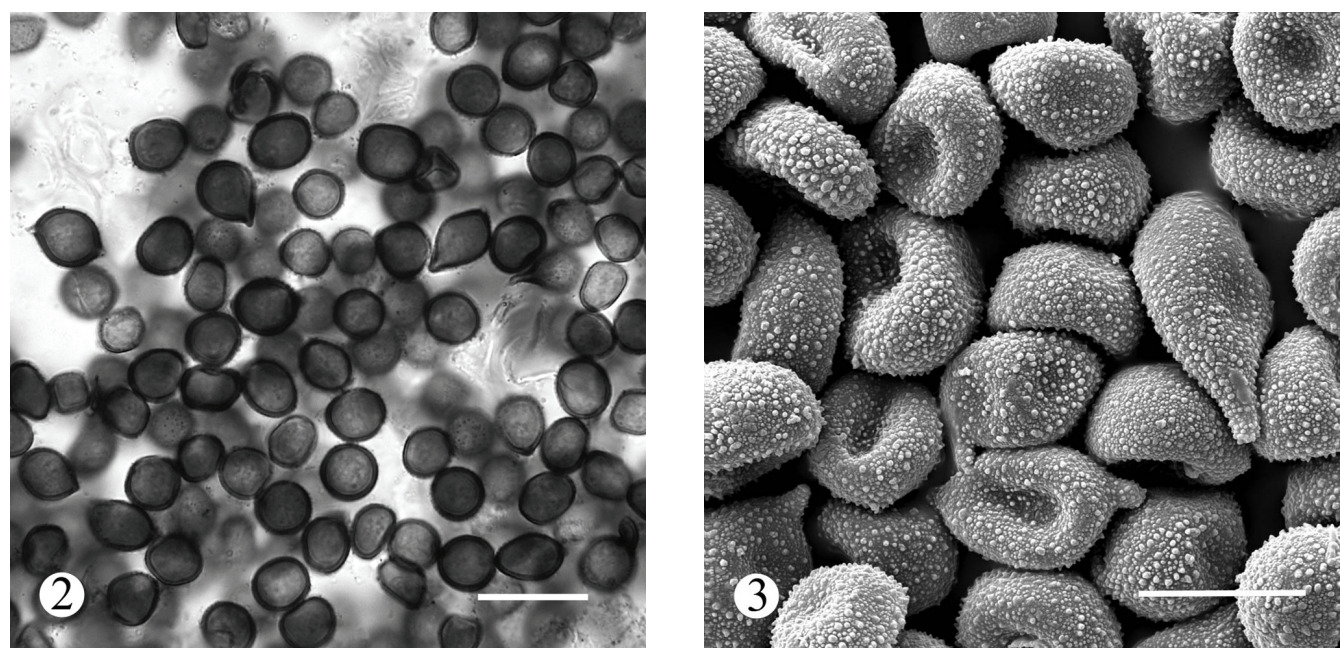

Figs 2, 3. Sporisorium emariae on Sclerachne punctata (holotype, H.U.V. 21 981). 2. Spores and sterile cells in LM. 3. Spores in SEM. Remark the acute tips of a few, ellipsoidal spores. Bars $=10 \mu \mathrm{m}$

\section{Taxonomy}

Sporisorium emariae Vánky, sp. nov.

MYcoBAnK MB 802779

Type on Sclerachne punctata, Asia, Republic of Georgia (Transcaucasia), 9 October 1907 (no further data are available) (holotype, Herb. Ustil. Vánky, H.U.V. 21 981!; isotype, BRIP 57995 - a slide).

Sori (Fig. 1) destroying the proximal, fertile part of all racemes of an inflorescence, irregularly cylindrical, 1-2 × 5-7 mm, on the top with a few, deformed glumes of aborted male spikelets, nearly completely hidden by leaves, covered by a thick, pale brown peridium which, at maturity, ruptures irregularly in several places disclosing the blackish brown, semiagglutinated to powdery mass of spores and sterile cells surrounding one to several, well-developed columellae. Spores (Figs 2, 3) when mature single, globose, subglobose, ellipsoidal or lemon-shaped, often with one or two acute tips, 5.5-10.5 $\times 7-13.5 \mu \mathrm{m}$, yellowish brown; wall even, $0.5-0.8 \mu \mathrm{m}$ thick, moderately densely, finely punctate- to verruculose-echinulate, spore profile smooth to finely, sparsely serrulate. In SEM spore surface provided with rounded or subacute warts and between them numerous, small verrucae. Sterile cells (Fig. 2) in irregular groups, single cells 10-20 $\mu \mathrm{m}$ long, hyaline or subhyaline; wall evenly $0.5-1 \mu \mathrm{m}$ thick, smooth.

On Poaceae: Sclerachne punctata R. Br.

Distribution: Asia (Republic of Georgia). Known only from the type collection.

Etymology. This species is named to thank a clever and beautiful Hungarian woman, who has given me encouragement and happiness, despite of long distance. 
The nine known smut fungi of the subtribe Chionachninae are: 1) Sporisorium polytocae (Mundk.) Vánky, 2) S. polytocae-barbatae (Mundk.) Vánky, 3) S. polytocae-digitatae Vánky, 4) S. reilianum (J.G. Kühn) Langdon \& Full., 5) S. simile R.G. Shivas \& J. Walker, 6) Tilletia chionachnes Vánky, C. Vánky \& R.G. Shivas, 7) T. kimberleyensis Vánky \& R.G. Shivas, 8) T. puneana Vánky, and 9) Ustilago sclerachnes Wakef. ex Vánky. The differences between these and Sporisorium emariae are shown in a key.

Key to the smut fungi of Chionachne, Polytoca, and Sclerachne

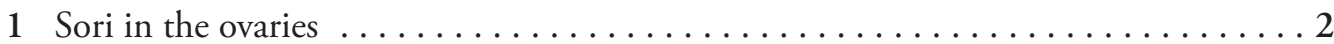

$1^{*}$ Sori in the spikelets, racemes or in the whole inflorescence $\ldots \ldots \ldots \ldots \ldots \ldots 5$

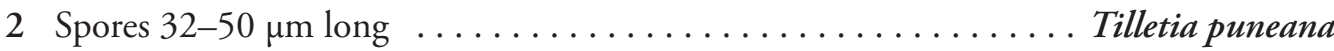

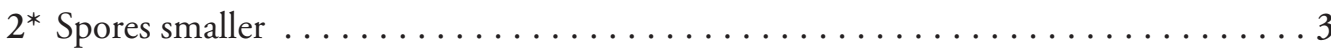

3 Spores $23-36 \mu \mathrm{m}$ long $\ldots \ldots \ldots \ldots \ldots \ldots \ldots \ldots$ Tilletia chionachnes

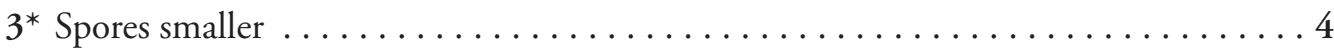

4 Spores $16-24(-26) \mu \mathrm{m}$ long $\ldots \ldots \ldots \ldots \ldots \ldots \ldots$ Tilletia kimberleyensis

$4^{*}$ Spores $5.5-6.5 \mu \mathrm{m}$ long $\ldots \ldots \ldots \ldots \ldots \ldots \ldots \ldots \ldots$ Ustilago sclerachnes

5 Sori in the whole inflorescence; columella much branched $\ldots \ldots \ldots \ldots \ldots \ldots 6$

$5^{*}$ Sori in the spikelets or racemes; columella not much branched $\ldots \ldots \ldots \ldots \ldots 7$

6 Spores $8-10.5 \mu \mathrm{m}$ long, prominently echinulate ........... Sporisorium simile

6* Spores 10.5-14.5 $\mu \mathrm{m}$ long, densely, minutely echinulate .... S Sporisorium reilianum

7 Spores 6.5-11 $\mathrm{m}$ long, without acute tips ....... Sporisorium polytocae-barbatae

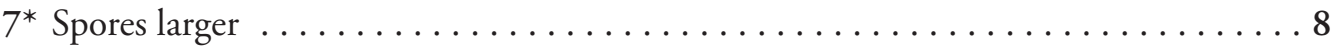

8 Spores 7-13.5 $\mu \mathrm{m}$ long, often with acute tips $\ldots \ldots \ldots \ldots$ Sporisorium emariae

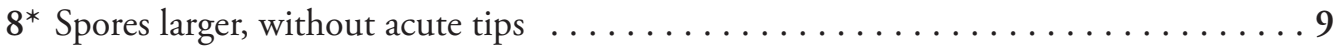

9 Spores 11-15 $\mu \mathrm{m}$ long, mostly subpolyhedrally irregular, finely punctate-echinulate, spore profile smooth to finely serrulate $\ldots \ldots \ldots \ldots \ldots$. Sporisorium polytocae

9* Spores 9.5-16(-19) $\mu \mathrm{m}$ long, mostly rounded, evidently echinulate; spore profile serrate Sporisorium polytocae-digitatae

Sporisorium emariae differs from other smut fungi on Chionachne, Polytoca, and Sclerachne in that the sori destroy the proximal, fertile part of the racemes, and have many ellipsoidal spores with one or two acute tips. McTaggart et al. (in press) revised the Ustilago, Sporisorium and Macalpinomyces complex. The genera Sporisorium and Anthracocystis were emended, and three new genera, Langdonia, Stollia, and Triodiomyces have been described. According their criteria, the smut fungus on Sclerachne punctata belongs to the genus Sporisorium. 
Acknowledgements. I am grateful to Dr. Roger Shivas (Brisbane, Australia) for critically reading the manuscript and useful suggestions. The technical assistance of Mrs. Christine Vánky (HUV, Tübingen, Germany) with the illustrations, and that of Mrs Monika Weinert (University, Tübingen, Germany) with the SEM picture of the spores, is gratefully acknowledged.

\section{References}

Bor, N.L. 1960. The grasses of Burma, Ceylon, India and Pakistan (excluding Bambuseae). Pergamon, New York.

Brummitt, R.K. \& Powell, C.E. 1992. Authors of plant names. Royal Botanic Gardens, Kew, UK.

Clayton, W.D. \& Renvoize, S.A. 1986. Genera graminum. Grasses of the world. Kew Bulletin, Additional Series 13. London, UK.

Clinton, G.P. 1904. North American Ustilagineae. - Proceedings of the Boston Society of Natural History 31: 329-529.

Jannink, T.A. \& Veldkamp, J.F. 2002. A revision of Chionachninae (Gramineae: Andropogoneae). - Blumea 3: 545-580.

McTaggart, A.R., Shivas, R.G., Geering, A.D.W., Vánky, K. \& Scharaschkin, T. In press. A taxonomic revision of Ustilago, Sporisorium and Macalpinomyces. - Persoonia.

Vánky, K. 2008. Taxonomic studies on Ustilaginomycetes - 28. - Mycotaxon 106: 133-178.

Vánky, K. 2011('2012'). Smut fungi of the world. APS Press, St. Paul, Minnesota, USA.

Zundel, G.L. 1953. The Ustilaginales of the world. - Pennsylvania State College School of Agricultre, Department of Botany Contribution 176: I-XI + 1-410. 
